\title{
The role of cohousing in social communication and sustainable living environments
}

\author{
J. Wang ${ }^{1}$, K. Hadjri ${ }^{1}$, S. Bennett ${ }^{2}$ \& D. Morris ${ }^{3}$ \\ ${ }^{1}$ School of Architecture, The University of Sheffield, UK \\ ${ }^{2}$ School of Art, Design and Fashion, \\ University of Central Lancashire, UK \\ ${ }^{3}$ School of Social Work, Care and Community, \\ University of Central Lancashire, UK
}

\begin{abstract}
Cohousing is a new form of human settlement which offers a possible solution to the housing crisis. In cohousing communities, people come together and share facilities and belongings, such as a garden, central workshops and car. The energy efficiency contributes to a reduced cost of living for tenants. Equally, cohousing and its community have the potential to offer a different scale of social organisation whilst delivering an environmental concept that leads to a low carbon lifestyle. This paper will present work conducted as part of a $\mathrm{PhD}$ study which aims to examine the timeline and consequences of a green agenda moving towards a sustainable living model, by exploring debates around cohousing and sustainable communities and social interaction. Examining people's contemporary lifestyles as a starting point, this research will develop methods to encourage a greater commitment to cohousing and sustainable living environments. This paper will review two case studies in order to examine the role of cohousing in creating sustainable living environments in the UK. Cohousing concepts will be analysed according to size and features, community structures, cultural and economic values. How cohousing can be utilised as an evaluation tool for social sustainability, to guide behavioural change and foster sustainable living will be examined. Additionally, it is anticipated that the information produced by this research could potentially be applied to different settings and environments in the UK and beyond, accelerating the implementation of environmentally-friendly homes and communities.

Keywords: cohousing, social communication, sustainable living environments, low carbon lifestyle, affordable housing.
\end{abstract}




\section{Introduction}

At the beginning of the 21 st century, it is undeniable that greenhouse gases and global warming triggered serious problems in different aspects of people's lives [1]. It is now time to consider and enforce targets to reduce carbon emissions on a global scale. With increased awareness, people feel the necessity to move towards a green and sustainable lifestyle. If social dynamics could change by creating or rebuilding communities that are denser, resilient and more habitable [2], then cohousing would emerge as a new housing model in answer to the housing crisis and social change.

The cohousing concept is well established in Denmark, Sweden, Germany, the UK and the US. An increasing cohousing movement includes some of the most innovative, supportive, energy-efficient, social and sustainable developments all over the world. A growing number of housing practitioners, funders and policy makers have started to consider cohousing as an ideal and realisable model for sustainable and affordable housing development [3]. At the moment, there are diverse types of cohousing around the UK, such as affordable cohousing (LILAC), cohousing for older people (Older Women Cohousing), Eco-village (Cambridge Community Land Trust), and vegetarian cohousing (Veganic Cohousing).

To what extent and how cohousing could provide solutions for sustainable housing and communities will be discussed within the perimeters of: (1) cohousing characteristics; (2) neighbourhood design; (3) residents' management and social interaction; and (4) sustainable living and affordability.

This paper will examine, through an exploratory case study analysis the value of cohousing with the aim to understand its role in building sustainable and affordable communities.

\section{Background}

The term "cohousing" comes from "co-operative housing" and is a housing model which offers a possible solution to the housing crisis [4]. It is a new collaborative housing concept designed to foster meaningful relationships, social interaction and energy efficiency concepts. The origin of cohousing began in Denmark in the 1960s [4]. It was first developed to achieve social interaction and community cohesion in Denmark and the Netherlands [5]. Subsequently, cohousing design is to be found mainly in Sweden, The Netherlands, Denmark, the UK and North America [6]. Through cohousing, residents are committed to living together as a community and gain the benefit of a supportive social network [3]. According to Field [7], the basic conditions for cohousing are established from (a) intentionality; (b) design for facilitating the processes of socialisation; (c) presence of private and common facilities; (d) group size to support the community dynamics; and (e) control and self-management.

Residents are encouraged to participate in the physical layout design, space planning, common facilities sharing and management of their own neighbourhood [3]. In particular, Sargisson [8] pointed out, "consensus" is the heart of the system of governance in cohousing communities even if it requires time, patience, funds 
and a strong willingness to solve the internal and external issues. The criteria of identifying cohousing is not only the degree of sharing and the quality of facilities, but also the communication with the outside world [6].

A cohousing community is a group of between 8 and 40 households who come together and share facilities and belongings. The community may reduce the living costs by shared resources, education and other social services, such as gardens, cars, workshops, child and elderly care, caregiver support, tutoring and training $[3,4]$. In fact, as stated by the UK Cohousing Network, cohousing communities have a common house, with shared facilities such as cooking and dining spaces, meeting and playing areas, laundries and guest rooms. Shared outside space for children's play, parties and gardening can feature in a cohousing project.

Additionally, the main aim in cohousing communities is to minimise living costs, such as rent, car ownership, and energy consumption [9]. Secondly, it aims to create a "friendly neighbourhood" to redefine the relationships among neighbourhood units [8]. Finally, it creates a special network by encouraging social interaction because of close inhabitation in a "community environment", whilst maintaining an element of privacy and independence [6]. As Sargisson [8] highlighted, cohousing and its communities are based on a concept of sharing, not only spaces and facilities, but also properties, decision-making processes and life experiences.

\subsection{Social interaction in cohousing communities}

Social interaction is a key component of cohousing communities. The establishment of cohousing communities requires efficient communication between its members, designers and builders. The following sections discuss cohousing design, resident's participation and decision-making.

\subsubsection{Neighbourhood design and resident participation}

When discussing neighbourhood design of cohousing, it is vital to define "consensus". Consensus is the core of a cohousing community, and it becomes the underlying principle of people living together [10]. According to Hare [11], it has been defined as a solution to satisfy all members or participants. Additionally, consensus can be applied to measure the degree of democratic contribution [12]. Furthermore, a consensus model is capable of leading a decision-making process and enhancing the relationship within the group [10]. In other words, it has been utilised as a decision rule in group cooperative activities [12].

The goal of cohousing is to create a vibrant social environment with enhanced community support and care [13]. Resident cooperation and participation start with neighbours who get to know each other through frequent activities $[3,6]$. In particular, the participative process allows people to develop a sense of ownership and foster a sense of group cohesion and belonging (Brenton [14]). Equally, it can benefit every resident; for instance, there would be a neighbour who would babysit at short notice and has the ability to teach children [15]. According to Glass [16], some of the primary activities in a cohousing community are residents' association meetings, attending and preparing the common meals and outdoor maintenance 
(see Table 1). The neighbourhood design and residents' participative activities are evidence of effective social communication.

Table 1: Participation in common activities. (Source: Glass [16, p. 356].)

\begin{tabular}{|l|c|}
\hline Common activity & Percentage \\
\hline Residents' association meetings & 96.9 \\
\hline Attend common meals regularly & 84.4 \\
\hline Other committees & 67.7 \\
\hline Preparing common meals & 65.6 \\
\hline Outdoor maintenance & 56.3 \\
\hline Planning special events & 56.3 \\
\hline Indoor maintenance and cleaning & 50.0 \\
\hline Common exercise activities & 46.9 \\
\hline Common hobby activities & 31.3 \\
\hline Steering committee/ board & 28.1 \\
\hline Coffee meetings & 12.5 \\
\hline
\end{tabular}

\subsubsection{Resident decision-making}

As Garciano [3] highlighted, in a cohousing community, the result of each proposal and operational decision has to address all potential concerns. The consensus model can be used to examine and ensure that group policies and decisions made are suitable for the whole community. For example, the design of the community, required social work for each family. On the other hand, the consensus model can be seen as a "river", which means the model might be elaborated as flowing to its conclusion [10]. The metaphor implies that the consensus has the ability to promote the natural, positive, continuous movement in the decision-making process.

Correspondingly, the consensus model provides a method that allows each group member to consider and discuss ideas openly [10], and also provides new perspectives for the neighbourhood. A resident from Brich Haven Cohousing (located in Wisconsin, America) stated: "Some way to make a clearing where we can all step out of what we came in wanting, expecting, hoping for, and stand in a place together where we can begin to see a new way or something different" $[10$, p. 360].

Alternatively, there are some difficulties with the current understanding and application of consensus. Some investigators consider consensus as a packaged solution whilst others view it as a process [10], and different points of view will make the decision-making process more difficult. The decision-making of the community will be influenced by a stakeholder's age, educational level, culture, life experiences, incomes and other social factors. Moreover, each cohousing community is unique, there is no "one-size fits all" societies and communities. In other words, it is difficult to be effective; cohousing owners and residents need to deal with each issue according to the agreed rules in the concerned community. It is also limited by the size of the community, and some communities have a process 
for making "small decisions" without full group interaction. Therefore, there is a need for more social support in community decision-making particularly for large communities.

\subsection{Sustainable living}

Cohousing can be an innovative community model to enhance residents' interaction with each other and with nature [13]. Some cohousing settlements analysed in this research showed a better environmental performance, such as LILAC and Lancaster cohousing.

"Sustainable living" is used to describe a person's lifestyle needs, whilst reducing the environmental footprint. The cohousing model is effective in inspiring people how to make their life greener and healthier. Sustainable technologies, housing design factors and mutual social interactions pertaining to sustainable practices could support people to achieve a low-carbon, even zerocarbon lifestyle [17]. Cohousing encourages people to adopt pro-environmental behaviours such as using a bike instead of a private car and reinforces the individual's commitment to sustainable practices. These include waste sorting, using less heat and hot water, and growing plants and vegetables [17]. The participative processes involved provide the connection between land and human activities, including recycling, energy-efficient systems and grey water systems [13].

LILAC project is a typical example which effectively represents what lowimpact, low carbon values mean in practice. LILAC employed a strawbale and engineered timber system called Modcell for the construction of each house. Although this system is currently more expensive than other traditional construction techniques such as brick, it delivers a low carbon footprint.

Cohousing communities also use more sustainable technologies built into houses [17], and attempt to keep the balance between having environmentally friendly technologies and what would be acceptable and affordable to residents.

\subsection{Affordability}

One key purpose of cohousing is to minimise the cost of the construction and maintenance [9], but some cohousing homes typically cost more than new standard town houses [6]), for the following reasons:

- Cohousing neighbourhoods provide generous common facilities that are unheard of in standard housing developments.

- The use of environmentally sustainable features and technologies are favoured in a cohousing community, such as biomass, ground heating, solar heating and rainwater harvesting system. These homes will cost more in the short term [18].

In this situation, low-income groups tend to be excluded from living in cohousing communities, because some of them cannot afford [3]. According to Rodman [19, p. 112], affordability is highly valued but is difficult to achieve. For many cohousing projects, there is an aim to balance values of affordability, 
aesthetics, design for physical accessibility and sustainability. Normally, the financial cost of cohousing is influenced by the same cost factors as all other types of housing; they include land prices, construction costs, development finance, community planning and maintenance costs [20]. At the same time, the cost of living is also affected by the size of the community. In other words, the number of households will directly influence the cost and the quality of living.

Some cohousing schemes provide financial support for the low- and moderateincome groups. For example, some communities assist their tenants with a wide range of affordable housing strategies, and internal and external subsidies.

\section{Research methodologies}

The research methodology is set out as a qualitative exploration of complex interdisciplinary questions around a very recent housing model - cohousing. This research aims at better understanding this housing model and explores the possibility and feasibility of further in-depth study [21]. The inquiry is divided into three key fields - social communication, physical design features and affordability - and uses case study strategy to explore how these three fields can contribute to sustainable living in a cohousing community.

The research aims to establish how cohousing may contribute to sustainable living environments. The approach considered in this research is based on collected data from literature review, case studies and in-depth interviews with residents.

\subsection{Case study}

Why is the case study approach best suited to this study? Yin [22, p. 4] suggests that "...the more the research questions seek to explain some present circumstance, the more that case study research will be relevant." In other words, the case study allows the investigators to understand a "case" in real-world perspective. In this study, alternative cases will help understand comprehensively different types of cohousing and sustainable communities, in order to know how they work, their advantages and limitations, how government policies influence people's lives. Moreover, another reason why the case study methodology was chosen is that it combines theories with reality and it can be part of the wider evaluation. Data gathered from the tenants and other stakeholders can play an influential role, with the findings from the evaluation helping to refine the contexts and guide further research.

\subsubsection{Selection criteria and case analysis}

This section will discuss the selection criteria of case studies which will depend on data availability and access, locations, stakeholder engagement and case concepts. Selection criteria are characteristics that the prospective cases and stakeholders must have if they are to be included in the study. The inclusion criteria of the research will consider the following aspects:

- The case location is in the UK and is accessible; 
- The characteristics of the case has to meet the definition of cohousing or sustainable communities;

- Valuable existing data is accessible, for example, the data can be found in books, journals and reliable websites;

- Different age groups, various kinds of stakeholders (architects, designers, householders, users and neighbours) are accessible;

- Environmentally-friendly technologies (biomass, thermal mass, solar panel and timber frame, etc.) are included;

- Shared facilities (cars, bikes washing machines, kitchen electric appliances, gardens. etc.) are present;

- Rainwater harvesting/collection systems are used;

- The co-housing development was built after 2000 .

Based on these selection criteria, Lancaster cohousing and the LILAC project have been chosen as two case studies for this preliminary study. The desktop review of these cases is summarised in Table 2.

Table 2: A desktop review of selected case studies

\begin{tabular}{|c|c|c|}
\hline & Lancaster cohousing & LILAC \\
\hline \multirow{5}{*}{ 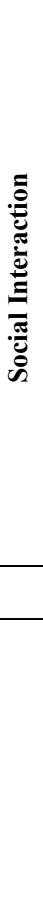 } & $\begin{array}{l}\text { Sharing contributes to social and } \\
\text { sustainable living. }\end{array}$ & Sharing contributes to social and sustainable living. \\
\hline & $\begin{array}{l}\text { SHARE PROPERTY. } \\
\text { Such as washing machines, land, bikes } \\
\text { and cars. One car for every three } \\
\text { households; website to show what } \\
\text { property is available to share with } \\
\text { others. }\end{array}$ & $\begin{array}{l}\text { SHARED PROPERTY. } \\
\text { Such as gardening tools, laundry facilities, kitchen, } \\
\text { play areas and cars. There are } 10 \text { parking spaces and } \\
\text { they have } 10 \text { cars between } 20 \text { households. }\end{array}$ \\
\hline & $\begin{array}{l}\text { SHARE DECISIONS. } \\
\text { The residents prefer to live with like- } \\
\text { minded people. The group discussion } \\
\text { comes up with common and possible } \\
\text { solution. It does not mean that } \\
\text { everyone has to agree, but it does mean } \\
\text { that everyone has to feel they can live } \\
\text { with the decisions that are made. }\end{array}$ & $\begin{array}{l}\text { SHARE THOUGHTS. } \\
\text { The community has an agreement as a guideline to } \\
\text { identify how the members want to live differently. It } \\
\text { established several things to manage the shared spaces } \\
\text { and individual behaviours, such as car parking, shared } \\
\text { meals, social activities etc. }\end{array}$ \\
\hline & Lancaster cohousing & LILAC \\
\hline & $\begin{array}{l}\text { SHARE SKILLS } \\
\text { Such as software skills and } \\
\text { communication skills. The children } \\
\text { can be taught by neighbours and } \\
\text { friends. They are a well-qualified } \\
\text { group; they have engineers, } \\
\text { environmental consultants, } \\
\text { accountants, a lawyer, a carpenter, a } \\
\text { nurse, a police officer. }\end{array}$ & $\begin{array}{l}\text { SHARE THOUGHTS. } \\
\text { Information is not available. }\end{array}$ \\
\hline
\end{tabular}




\begin{tabular}{|c|c|c|}
\hline & $\begin{array}{l}\text { Communal activities encourage social } \\
\text { interaction. For example, the } \\
\text { community has common meals three to } \\
\text { five times a week. }\end{array}$ & The community has common meals twice a week. \\
\hline & $\begin{array}{l}\text { The community was planned and } \\
\text { created by the people who live there. } \\
\text { They have more possibilities to meet } \\
\text { and discuss how to improve the } \\
\text { neighbourhood to make it more } \\
\text { efficient and greener. }\end{array}$ & $\begin{array}{l}\text { The community was planned and created by the } \\
\text { people who live there; they spent } 6 \text { years to solving } \\
\text { all problems since } 2006 \text {. Faced by economic crisis, } \\
\text { climate change and social isolation, this group of } \\
\text { people gathered together to make the community } \\
\text { function again. }\end{array}$ \\
\hline \multirow{4}{*}{ 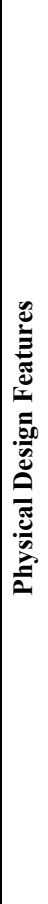 } & $\begin{array}{l}\text { HOUSE SIZE } \\
\text { The houses tend to be a little smaller, } \\
\text { because they have all communal space, } \\
\text { which also create opportunities for } \\
\text { social cohesion, save energy and land } \\
\text { to encourage sustainable living. }\end{array}$ & $\begin{array}{l}\text { HOUSE SIZE } \\
\text { LILACis comprised of } 20 \text { homes of different sizes. } \\
\text { There are one-bed, two-bed flats and three- or four- } \\
\text { bed houses. }\end{array}$ \\
\hline & $\begin{array}{l}\text { LAYOUT AND BUILDING } \\
\text { MATERIALS } \\
\text { The houses were designed by } \\
\text { architects Eco Arc using natural or } \\
\text { recycled materials, also the houses are } \\
\text { south facing so they have plenty of } \\
\text { natural light to warm by the sun. Also, } \\
\text { the common house is in the middle of } \\
\text { the community, which is convenient } \\
\text { for each house and creates } \\
\text { opportunities for social cohesion. }\end{array}$ & $\begin{array}{l}\text { LAYOUT AND BUILDING MATERIALS } \\
\text { There is a large common house in the middle of the } \\
\text { community. LILAC employed a strawbale and } \\
\text { engineered timber system called Modcell for the } \\
\text { construction of each house. LILAC members made a } \\
\text { decision that related to decreasing energy and space- } \\
\text { heating needs. They employed an energy consultant } \\
\text { from Progetic to generate energy choices according to } \\
\text { a list of criteria which LILAC members defined in } \\
\text { order to deliver a low impact, comfortable, reliable } \\
\text { and affordable living style. }\end{array}$ \\
\hline & $\begin{array}{l}\text { TECHNOLOGY } \\
\text { A single radiator is running for each } \\
\text { house, running from a biomass boiler. } \\
\text { They have solar panels and a } 160 \mathrm{~kW} \\
\text { hydro turbine in the River Lune to } \\
\text { supply electricity. A rainwater } \\
\text { harvesting system is available. }\end{array}$ & $\begin{array}{l}\text { TECHNOLOGY } \\
\text { Solar PV; Mechanical Ventilation with Heat } \\
\text { Recovery (MVHR), high-efficiency gas boilers with } \\
\text { solar thermal water-heating units. }\end{array}$ \\
\hline & $\begin{array}{l}\text { CSH level } 6 \text { certification } \\
\text { PassivHaus Standard Homes. }\end{array}$ & $\begin{array}{l}\text { CSH level } 4 \text { certification } \\
\text { Low Impact Living Affordable Community. }\end{array}$ \\
\hline 葛 & Information is not available. & $\begin{array}{l}\text { The community has a complicated ownership } \\
\text { structure. All members buy shares in the mutual } \\
\text { company which owns the site and properties. } \\
\text { Members pay a deposit equal to } 10 \text { percent of shares; } \\
\text { the households have been charged equivalent to } 35 \\
\text { percent of their net monthly income to accruing more } \\
\text { shares. If the residents want to leave LILAC, the } \\
\text { deposit will be repaid and they sell the shares they } \\
\text { own (Chatteron [23]). }\end{array}$ \\
\hline
\end{tabular}

The research examined the relationship between the social interaction of cohousing members, and the key features of a sustainable social and environmental settings. The following are the key findings from the desktop review: 
- Sharing (property, skills and experiences and thoughts) and communal activities encourage people to save time, money, land and energy.

- The self-management scheme will allow more possibilities to employ the greener and healthier resources in the cohousing community. The degree of cooperation is higher in Lancaster cohousing than in LILAC project.

- The innovative construction materials - such as strawbale and timber reduce the energy consumption and promote low impact lifestyles.

- The sustainable technologies such as Biomass and Solar energy promote energy efficiency in the cohousing community, but the latest technology devices and their maintenance are expensive. The level of sustainability of Lancaster cohousing is higher than LILAC.

- $\quad$ The LILAC scheme has a sophisticated ownership structure, which means the affordability issues are well addressed in this cohousing scheme. In other words, the residents are encouraged to spend less and live greener and healthier lives. There is no information about affordability for Lancaster cohousing.

\subsubsection{Site visits}

The visits were conducted to view the facilities, meet residents, understand the background of these two cases, and to assist the subsequent interviews with residents.

Lancaster cohousing project is located in the village of Halton next to the river Lune. There are around 65 adults and 15 children who live there. The coordinators and residents were inspired by the sustainable "eco" design concept; the homes have achieved both Passivhaus and Code for Sustainable Homes (CSH) level 6 certification.

The LILAC project is a typical example which effectively represents what lowimpact, post-carbon values mean in practice. According to the coordinator of the

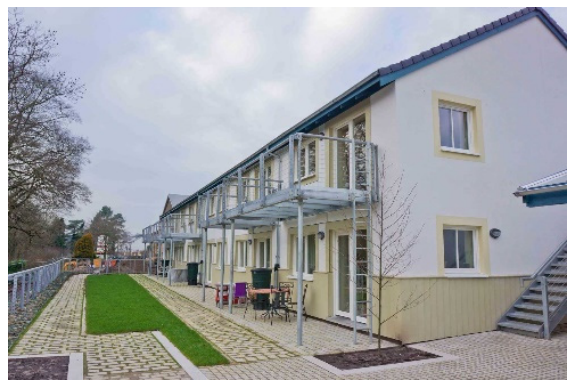

Figure 1: Lancaster cohousing.

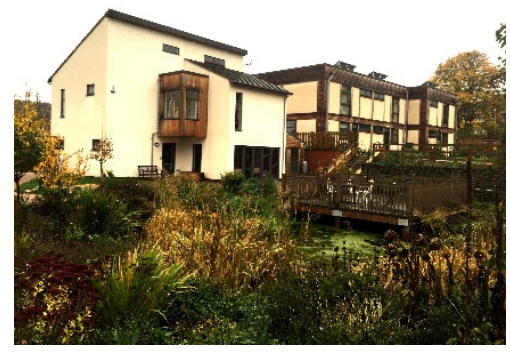

Figure 2: LILAC project in Leeds.

LILAC Community [23], the project translates low impact living from an idea to a reality, which has become such a challenge because it involves debates not just about technological change but also in terms of value, cultural and institutional 
change. The homes have achieved the Code for Sustainable Homes (CSH) level 4 certification.

\subsection{Lancaster cohousing residents' interview}

In-depth interviews were conducted at Lancaster cohousing to seek a better understanding of the complexity of this case study through feedback from stakeholders. Although several attempts were made to arrange interviews at LILAC, this has not been possible. The interview data will guide the direction of the $\mathrm{PhD}$ research. Based on the results of the literature review, five questions were devised, divided into three groups:

- Social interaction. Key questions on social interaction are concerned with what motivates individuals to create/choose a cohousing community, and whether social cohesion emerges as a primary factor, but also how can social cohesion contribute to sustainable living?

- Physical design features. The type of housing design can support sustainable living within the cohousing context and can contribute to sustainability. Why people choose to move into a cohousing community and what are the most important reasons for this choice?

- Affordability. How can cohousing be an affordable option?

The interviewees at Lancaster cohousing were two cofounders and a resident. The aim was to understand their motivation, cohousing neighbourhood design, sustainability concerns and affordability. The key findings from these interviews are presented in Table 3.

Key findings from interviews reflected residents' motivations and their interests in cohousing communities, and also showed that the Lancaster cohousing model is going to become a practical cohousing prototype to lead low-carbon and sustainable lifestyles in the UK. Positive social interaction, sustainable design and affordability are highly valued and contribute to the cohousing philosophy. Affordability however remains a challenge for some cohousing given the high costs of creating low carbon housing.

\section{Conclusions}

Cohousing can be seen as a progressive commitment to foster social interaction, sustainability and affordable living. Cohousing schemes can be driven by various economic, social and environmental objectives, and their successful realisation depends on community cohesion and shared values, and the strategic use of affordable sustainable housing designs and construction methods. This exploratory study provides directions to the $\mathrm{PhD}$ study in terms of the key issues facing cohousing in terms of social interaction, sustainability and affordability.

Further research will target different age groups including participants such as older people and women, to better understand the value of cohousing in creating sustainable living and sustainable communities. 
Table 3: Lancaster cohousing interview data analysis.

\begin{tabular}{|c|c|}
\hline $\begin{array}{l}\text { SOCIAL } \\
\text { INTERACTION } \\
\text { (Motivations and } \\
\text { the important } \\
\text { considerations to } \\
\text { choose and live in a } \\
\text { cohousing } \\
\text { community) }\end{array}$ & $\begin{array}{l}\text { - Cohousing scheme could encourage like-minded } \\
\text { people to live together or closely. } \\
\text { - Sharing (tools, ideas, experiences, skills etc.) } \\
\text { contributes to social living. } \\
\text { - Offering close relationship with neighbours. } \\
\text { - Offering opportunities to learn about ourselves and } \\
\text { from each other's. Every resident was evolved at the } \\
\text { very early stage and support each other. } \\
\text { - Cohousing concepts are beneficial for community } \\
\text { building and intergenerational living. }\end{array}$ \\
\hline $\begin{array}{l}\text { SUSTAINABILITY } \\
\text { (Physical design } \\
\text { factors) }\end{array}$ & $\begin{array}{l}\text { - Sustainability need more achievable and a group } \\
\text { context. } \\
\text { - Sustainability becomes a symbolic idea, it helps } \\
\text { people to be practical and get inspired. } \\
\text { - Offering opportunities to live greener and healthier. } \\
\text { - Saving energy and low environmental impacts. } \\
\text { - Better environmental commitment and the } \\
\text { environmental technologies are helpful. }\end{array}$ \\
\hline AFFORDABLITY & $\begin{array}{l}\text { - Affordability is a challenge. The community scheme } \\
\text { could be made more affordable. } \\
\text { - Easy to live in, because of low energy costs and } \\
\text { sharing scheme; but expensive to buy a house, } \\
\text { especially for the young generation. }\end{array}$ \\
\hline
\end{tabular}

\section{References}

[1] Conran, T., Eco House Book, Conran Octopus: London, 2011.

[2] Steffen, A., The route to a sustainable future. [Video] TED: UK, 2005. www.ted.com/talks/alex_steffen_sees_a_sustainable_future.

[3] Garciano, J.L., Affordable cohousing: Challenges and opportunities for supportive relational networks in mixed-income housing. Journal of Affordable Housing \& Community Development Law, 20(2), pp. 169-192, 2011.

[4] Priest, I., Different kind of living. RIBA Journal, 122(10), p. 54, 2015.

[5] Williams, J., Designing neighbourhoods for social interaction: The case of cohousing. Journal of Urban Design, 10(2), pp. 195-227, 2005.

[6] Ruiu, M.L., Differences between cohousing and gated communities: A literature review. Sociological Inquiry, 84(2), pp. 316-335, 2014.

[7] Field, M., Thinking About Cohousing: The Creation of Intentional Neighbourhoods, Diggers and Dreamers Publications: London, 2004.

[8] Sargisson, L., Cohousing: A Utopian Property Alternative? Working Paper Series, Ref. WP014, University of Nottingham, 2010. 
[9] Thorne, A., Different kind of living. RIBA Journal, 122(10), pp. 54-56, 2015.

[10] Renz, M.A., The meaning of consensus and blocking for cohousing groups. Small Group Research, 37(4), pp. 351-376, 2006.

[11] Hare, A.P., Consensus versus majority vote. Small Group Behaviour, 11(2), p. 131,1980 .

[12] Collins-Jarvis, L., Participation and consensus in collective action organizations: The influence of interpersonal versus mass-mediated channels. Communication Research, 25(1), p. 16, 1997.

[13] Sanguinetti, A., Transformational practices in cohousing: Enhancing residents' connection to community and nature. Journal of Environmental Psychology, 40, pp. 86-96, 2014.

[14] Brenton, M., The Cohousing Approach to "Lifetime Neighbourhoods", Housing Learning and Improvement Network: London, 2008.

[15] Smith, C., Cohousing coming of age: "Intentional communities" one answer to an increasingly alienated society, 2002. www.sfgate.com/bayarea/ article/COHOUSING-COMING-OF-AGE-Intentional-2876444.php.

[16] Glass, A.P., Lessons learned from a new elder cohousing community. Journal of Housing for the Elderly, 27(4), pp. 348-368, 2013.

[17] Marckmann, B., Gram-Hanssen, K. \& Christensen, T., Sustainable living and co-housing: Evidence from a case study of eco-villages. Built Environment, 38(3), p. 413, 2012.

[18] Cohousing Partners 2012, How much does cohousing cost? http://cohousing-solutions.com/faq/\#12. Accessed on: 19 Jun. 2016.

[19] Rodman, M.C., Co-caring in senior cohousing: A Canadian model for social sustainability. Social Sciences Directory, 2(4), p. 106, 2013.

[20] Scanlon, K. \& Arrigoitia, M.F., Development of new cohousing: Lessons from a London scheme for the over-50s. Urban Research \& Practice, 8(1), p. 106, 2015.

[21] Torres-Antonini, M., Our common house: using the built environment to develop supportive communities. PhD thesis, University of Florida, 2001.

[22] Yin, R.K., Case Study Research: Design and Methods, 5th ed., SAGE: Los Angeles, CA, 2014.

[23] Chatterton, P., Towards an agenda for post-carbon cities: Lessons from LILAC, the UK's first ecological, affordable cohousing community. International Journal of Urban \& Regional Research, 37(5), pp. 16541674, 2013. 